\title{
THE PHYTOSOCIOLOGY AND SYNECOLOGY OF TASMANIAN VEGETATION WITH CALLITRIS
}

\author{
by S. Harris and J.B. Kirkpatrick
}

(with two tables, two text-figures and an appendix)

\begin{abstract}
Eleven discernible floristic plant communities were identified in vegetation containing Callitris in Tasmania. C. rhomboide and $C$. oblong $a$ largely segregate into two sets of communities. These sets occupy distinctly different parts of the environmental range of Callitris in Tasmania. Callitris co-occurs with at least $14 \%$ of the Tasmanian native higher plant flora in rainforest, wet eucalypt forest, dry eucalypt forest, grassy woodland, scrub and heath, and is dominant in some quadrats of most communities. The major measured correlates of floristic variation in the data set were temperature and precipitation conditions. The combination of the wide ecological range demonstrated by the data set and the highly restricted nature of Callitris distribution suggests that the taxon has a range much diminished by short-term perturbation. Callitris may have been part of an extensive dry rainforest formation in eastern Tasmania before people invaded the area.
\end{abstract}

Key Words: Callitris, dry rainforest, phytosociology, synecology.

In BANKS, M.R. et al. (Eds), 1991 (31:iii): ASPECTS OF TASMANIAN BOTANY - A TRIBUTE TO WINIFRED CURTIS. Roy. Soc. Tasm. Hobart: 179-189. https://doi.org/10.26749/rstpp.124.2.179

\section{INTRODUCTION}

Callitris is the only native gymnosperm genus found in the drier parts of Tasmania, where it is sporadically prominent within a range characterised by seemingly random absences and prominent disjunctions (Harris 1989). The gymnosperms of the wetter parts of Tasmania have suffered a considerable diminution of their ranges since European settlement (Kirkpatrick \& Dickinson 1984, Cullen \& Kirkpatrick 1988, Brown 1988). Experience elsewhere (e.g. Bowman et al. 1988) and some limited observations in Tasmania (Kirkpatrick 1977, Brown \& Bayly-Stark 1979a, Harris \& Brown 1980, Harris \& Kirkpatrick 1982, Duncan \& Duncan 1984, Duncan \& Brown 1985) suggested to us that Callitris was also in a state of retreat. The investigation reported herein is part of a larger study directed towards the long-term conservation management of Callitris species and communities in Tasmania. Later papers will discuss the autecology of $C$. rhomboidea and $C$. oblonga, their regeneration and stand dynamics, the history and palaeohistory of their distributions, and their conservation requirements.

In this paper we define and describe floristic communities within the range of Callitris, analyse their environmental relationships and discuss the implications of these results.

\section{METHODS}

During the summers of $1986 / 87,1987 / 88$ and 1988/89, floristic and environmental data were collected from $12610 \times 10 \mathrm{~m}$ quadrats distributed evenly throughout the range of Callitris in Tasmania. These data included floristic lists, height and cover by stratum, dominance, topographic position, the date of the last fire (where determinable from information, tree rings or growth whorls on Banksia), geomorphological situation (13 classes), slope, surface geology, altitude, drainage (three classes), slope aspect, soil texture (using the classes of Corbett 1969), soil depth and surface soil pH (using a CSIRO soil-testing kit). Class data, where possible, were arranged to form a continuous series. Thus, geologic classes were ordered from argillaceous to siliceous and slope aspect was scored from northwest to southeast to reflect the effect of exposure on insolation. Climatic data were derived from the extrapolated surfaces produced by the BIOCLIMmodelling package (Busby 1986).

The polythetic divisive classifactory program TWINSPAN (Hill 1979) was used to gain an initial sorted table which was reworked, where appropriate, using a table resorting program (Minchin 1986). Eleven communities were selected for description. The environmental relationships of the communities were determined using one-way analysis of variance.

Species nomenclature follows Buchanan et al. (1989). Structural nomenclature follows Duncan \& Brown (1985) where aposite, and Specht (1981) otherwise. 
TABLE 1

Percentage Frequency of Taxa Occurring in More than $40 \%$ of the Quadrats in Any One Group

$1=1-10 \%, 2=11-20 \%, 3=21-30 \%, 4=31-40 \%, 5=41-50 \%, 6=51-60 \%, 7=61-70 \%, 8=71-80 \%, 9=81-100 \%$.

\begin{tabular}{|c|c|c|c|c|c|c|c|c|c|c|c|}
\hline & 1 & 2 & 3 & 4 & 5 & 6 & 7 & 8 & 9 & 10 & 11 \\
\hline Holcus lanatus & 7 & - & - & 2 & - & - & 2 & - & - & - & - \\
\hline Cassinia aculeata & 9 & - & - & - & 1 & 1 & 2 & - & - & - & - \\
\hline Poa labillardieri & 9 & 7 & - & - & - & 1 & - & -. & 1 & - & - \\
\hline Rosa rubiginosa & 4 & 5 & - & - & - & - & 2 & - & - & - & - \\
\hline Melaleuca gibbosa & - & 6 & 3 & - & - & - & - & 1 & - & - & - \\
\hline Schoenus apogon & - & 5 & - & 2 & 2 & - & - & - & - & - & - \\
\hline Eucalyptus ovata & 4 & 8 & 3 & 1 & - & 1 & - & - & - & - & - \\
\hline Acacia dealbata & 7 & 4 & 2 & 5 & 2 & 2 & - & - & - & - & - \\
\hline Eucalyptus viminalis & 7 & 4 & 2 & 4 & 7 & 5 & 6 & - & 1 & - & - \\
\hline Leptospermum lanigerum & 4 & 5 & 2 & 2 & 2 & 2 & 2 & 1 & - & - & - \\
\hline Plantago lanceolata & 4 & - & 2 & - & 1 & 1 & 6 & - & - & - & - \\
\hline Ulex europaeus & 4 & 2 & 9 & 1 & 1 & - & 4 & - & - & - & - \\
\hline Acaena novae-zelandiae & 4 & 2 & - & 2 & 2 & 6 & 8 & - & - & - & 2 \\
\hline Bursaria spinosa & 4 & 2 & 5 & 3 & 7 & 5 & 8 & - & - & 3 & - \\
\hline Callitris oblonga & - & 9 & 9 & 2 & 1 & 1 & 4 & 1 & - & - & - \\
\hline Banksia marginata & - & 2 & 3 & 6 & 2 & 4 & 4 & 5 & - & - & - \\
\hline Epacris impressa & - & 5 & - & 7 & 4 & 2 & 2 & 3 & - & - & - \\
\hline Lomandra longifolia & - & 7 & 9 & 6 & 8 & 2 & 6 & - & - & - & - \\
\hline Bossiaea prostrata & - & 3 & 2 & 2 & 5 & 1 & - & - & - & - & - \\
\hline Callistemon paludosis & - & 1 & 5 & 1 & 2 & 1 & - & - & 1 & - & - \\
\hline Gonocarpus tetragynus & - & 3 & - & 3 & 5 & 1 & - & - & - & - & - \\
\hline Hibbertia riparia & - & 1 & 2 & 4 & 5 & - & - & 1 & - & - & - \\
\hline Astroloma humifusum & - & 1 & - & 6 & 8 & 2 & - & - & 1 & - & - \\
\hline Hypochaeris radicata & - & 2 & 2 & 2 & 1 & - & 6 & - & - & 2 & - \\
\hline Oxalis corniculata & - & 1 & 2 & 3 & 4 & 7 & 9 & - & 1 & 2 & - \\
\hline Lepidosperma elatius & - & 3 & 2 & 4 & 6 & 9 & 2 & - & 4 & - & 2 \\
\hline Pomaderris apetala & - & 2 & 6 & - & 2 & 8 & 8 & - & - & - & 6 \\
\hline Micranthe um hexandrum & - & - & 6 & - & 2 & 1 & 2 & - & - & - & - \\
\hline Gonocarpus micranthus & - & - & 6 & - & 1 & - & 2 & 1 & - & - & - \\
\hline Leptospermum scoparium & - & - & 2 & 5 & 2 & 2 & - & 5 & 4 & - & - \\
\hline Acacia verticillata & - & - & 3 & 2 & 2 & 7 & 2 & 2 & 1 & - & - \\
\hline Melaleuca ericifolia & - & - & 3 & 2 & 1 & 2 & 2 & 2 & 5 & 3 & - \\
\hline Allocasuarina verticillata & - & - & 2 & 2 & 3 & 1 & 2 & 2 & 7 & 3 & 2 \\
\hline Dodonaea viscosa & - & - & 2 & 1 & 2 & 2 & - & 1 & 1 & 6 & 2 \\
\hline Acacia mucronata & - & - & 3 & - & 4 & 2 & 2 & 8 & 7 & - & 4 \\
\hline Notelaea ligustrina & - & - & 3 & - & 4 & 3 & - & - & 1 & - & 6 \\
\hline Callitris rhomboidea & 9 & - & - & 9 & 9 & 9 & 8 & 9 & 9 & 9 & 9 \\
\hline Eucalyptus globulus & - & - & - & 3 & 3 & 7 & 4 & 6 & 2 & - & 6 \\
\hline Pteridium esculentum & - & - & - & 5 & 2 & 6 & 2 & 2 & 4 & - & 2 \\
\hline Pultenaea daphnoides & - & - & - & 1 & - & 2 & - & 1 & 5 & - & - \\
\hline Viola hederacea & - & - & - & 3 & 5 & 5 & - & 1 & - & - & - \\
\hline Lepidosperma lineare & - & - & - & 2 & 5 & - & - & 1 & - & - & - \\
\hline Poa rodwayi & - & - & - & 1 & 7 & 1 & - & - & - & - & - \\
\hline Eucalyptus pulchella & - & - & - & - & 6 & 4 & 2 & - & - & - & 2 \\
\hline Coprosma quadrifida & - & - & 2 & - & 1 & 6 & - & - & - & - & 4 \\
\hline Beyeria viscosa & - & - & 3 & - & 2 & 5 & 2 & - & - & - & 8 \\
\hline Asplenium flabellifolium & - & - & - & 1 & 2 & 4 & - & - & - & - & 8 \\
\hline Bedfordia salicina & - & - & - & 2 & - & 3 & - & - & - & - & 6 \\
\hline Ctenopteris heterophylla & - & - & - & - & - & 2 & - & - & - & - & 8 \\
\hline Rumohra adiantiformis & - & - & - & - & - & 1 & - & - & - & - & 6 \\
\hline Microsorum diversifolium & - & - & - & - & - & 2 & - & 1 & 1 & - & 6 \\
\hline
\end{tabular}




\begin{tabular}{|c|c|c|c|c|c|c|c|c|c|c|c|}
\hline & 1 & 2 & 3 & 4 & 5 & 6 & 7 & 8 & 9 & 10 & 11 \\
\hline Leptospermum glaucescens & - & - & - & - & - & - & - & 5 & - & - & - \\
\hline Leptospermum laevigatum & - & - & - & - & - & - & - & 5 & 6 & 9 & - \\
\hline Rhagodia candolleana & - & - & - & - & - & - & - & 1 & 1 & 5 & - \\
\hline Leucopogon parviflorus & - & - & - & 2 & - & - & - & 2 & 1 & 6 & - \\
\hline Poa poiformis & - & - & - & 1 & - & -- & - & - & 1 & 5 & - \\
\hline Crassula sieberana & - & - & - & 1 & 1 & - & - & 1 & - & 5 & 2 \\
\hline Bromus diandrus & - & - & - & - & - & - & 2 & - & - & 6 & - \\
\hline Polycarpon tetraphyllum & - & - & - & - & - & - & - & - & - & 5 & \\
\hline
\end{tabular}

\section{THE COMMUNITIES AND THEIR ENVIRONMENTS}

\section{Structural Variation}

Callitris oblonga occurred most frequently in woodland, scrub and shrubland dominated by Eucalyptus, the. most common dominants being $E$. ovata and E. viminalis, followed by E. amygdalina (table 1). $C$. oblonga was the next most common dominant (table 2), forming a scrub or shrubland. Other noneucalypts dominating scrub or shrubland with C. oblonga included Leptospermum lanigerum, L. scoparium, Melaleuca pustulata, Hakea microcarpa, Acacia mucronata and Pomaderris apetala.

In contrast to $C$. oblonga, $C$. rhomboidea was as common in open forest as in woodland, scrub or shrubland. C. rhomboidea also occurred in closed forest and heath. A wide range of eucalypt species was recorded as dominant in vegetation with $C$. rhomboidea. This range included E. globulus, E. viminalis, E. amygdalina, E. obliqua, E. pulchella, E. tenuiramis, E. ovata, E. nitida and E. regnans. C. rhomboidea was the most common non-eucalypt dominant. Others included Allocasuarina verticillata, Melaleuca ericifolia, Leptospermum laevigatum, Kunzea ambigua and Banksia marginata.

\section{Floristic Communities}

A list of all higher plant species observed in association with Callitris in Tasmania is given in the appendix. The percentage frequency of each abundant observed taxon in each of the 11 communities discussed below is presented in table 1 . The community distributions are shown in figure 1 and their environmental characteristics are shown in figure 2 . They are named by the most common dominant species and structural type, by the species of Callitris present and by the most characteristic (i.e. constant and faithful) other species. The dominant and most characteristic species are not necessarily highly constant within each group, as dominance was not an input to the classificatory procedure and characteristic species are defined by fidelity. Thus, the titles indicate a nodum of variation.

(1) Eucalyptus viminalis-Callitris rhomboideaCassinia aculeata shrubland - This is a community of silty, flat, near-coastal sites. The few quadrats in this group have been invaded by exotic grasses and herbs. It occurs on significantly flatter sites than all other communities and on significantly warmer sites in winter than community (2). Disturbance, leading to the invasion of exotics, may largely account for its distinctiveness. (2) Eucalyptus ovata-Callitris oblonga-Melaleuca gibbosa shrubby woodland - This is the community of alluvial river flats. It is most closely related to community (3), which occurs in more rocky riparian situations. It extends into colder winter environments than all others but (3) and (11), and occurs in areas of much lower precipitation, especially during the drier months, than community (11).

(3) Callitris oblonga-Callistemon paludosus tall open shrubland - This community occurs on rocky riparian sites on the South Esk, Apsley and Swan Rivers. Dolerite is the dominant rock. The community is typically heavily invaded by Ulex europaeus. It occurs in areas with lower precipitation during the driest months than communities (4), (5), (6) and (11) and lower winter temperatures than communities (4), (7), (8), (9) and (10).

(4) Eucalyptus amygdalina-Callitris rhomboideaEpacris impressa shrubby woodland - E. obliqua, E. globulus and $E$. viminalis are also occasionally dominant in this community, which extends from Tasman Peninsula to Bicheno on sandy sites in relatively moist areas and on skeletal dolerite soils where precipitation is high. The community is in the middle part of the climatic range on all variables. It occurs on significantly more sandy sites than group (6) and significantly more acid sites than communities (5) and (6). It differs environmentally from most other communities in its climatic characteristics.

(5) Eucalyptus pulchella/E. viminalis-Callitris rhomboidea-Poa rodwayi woodland - This is the community of dry and rocky, dolerite sites, i.e. either 

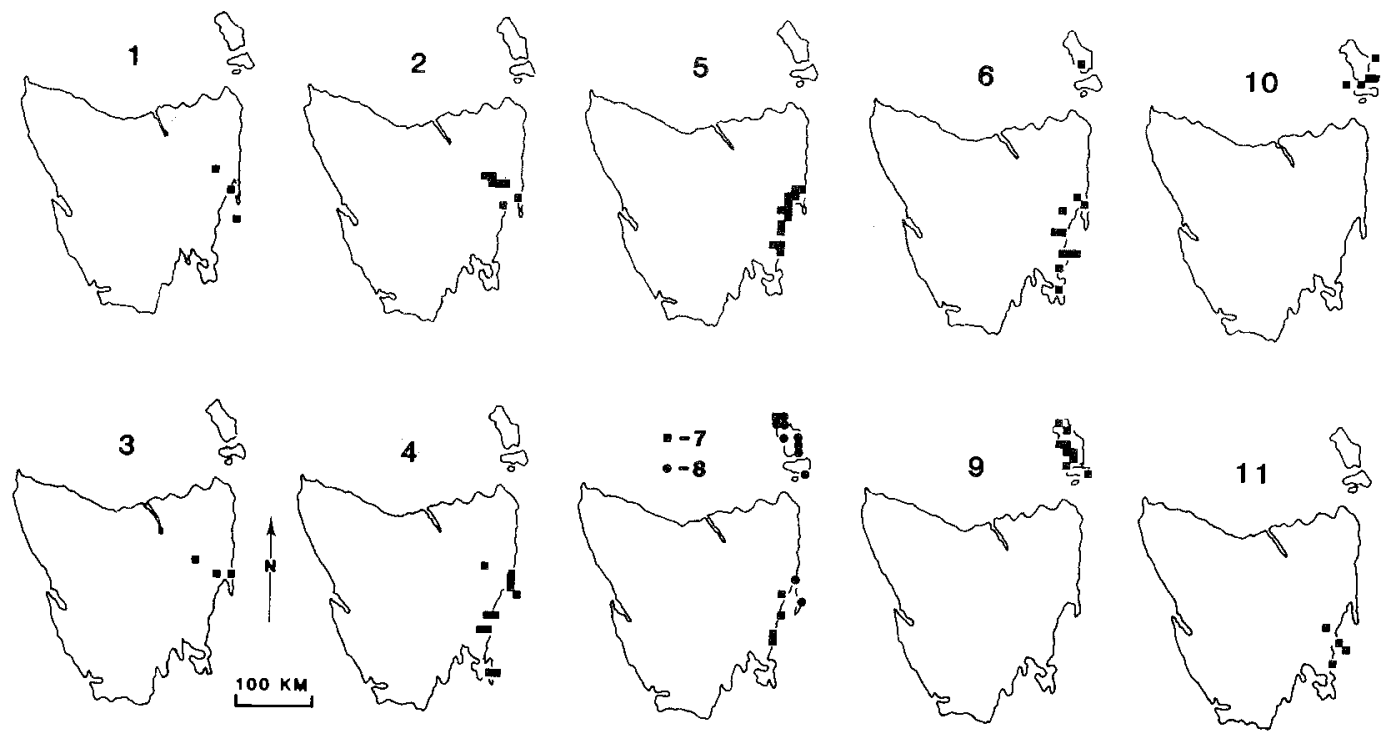

FIG. 1 - The distribution of the Callitris communities.

TABLE 2

The Proportion of Quadrats in Classificatory Groups

Dominated by Non-Eucalypt Genera

\begin{tabular}{|c|c|c|c|c|c|c|c|c|c|c|c|}
\hline \multirow{2}{*}{ Genus } & \multirow[b]{2}{*}{1} & \multicolumn{10}{|c|}{ Group } \\
\hline & & 2 & 3 & 4 & 5 & 6 & 7 & 8 & 9 & 10 & 11 \\
\hline Callitris & - & - & 62 & 6 & 8 & 7 & - & 24 & 62 & 100 & 40 \\
\hline Acacia & - & - & 12 & - & - & - & - & -- & - & - & - \\
\hline Allocasuarina & - & - & - & - & - & - & - & - & 13 & 14 & - \\
\hline Banksia & - & - & - & - & - & 7 & - & - & - & - & - \\
\hline Hakea & - & - & 25 & - & - & - & - & - & - & - & - \\
\hline Kunzea & - & - & - & - & - & - & - & - & 15 & 14 & - \\
\hline Leptospermum & - & - & 12 & - & - & - & - & 29 & 15 & 71 & - \\
\hline Leucopogon & - & - & - & - & - & - & - & - & - & 29 & - \\
\hline Melaleuca & - & - & 12 & - & 4 & - & - & - & 23 & 14 & - \\
\hline Pomaderris & - & - & 12 & - & - & 7 & - & - & - & - & - \\
\hline
\end{tabular}


GEOLOGY $\quad F=3.42 \quad p<.0001$

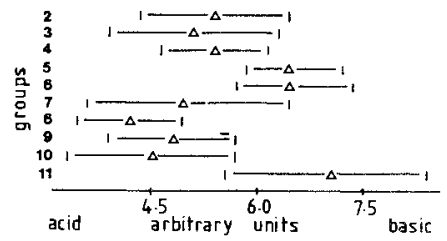

SOIL TEXTURE $\quad F=3.07 \quad P<.001$
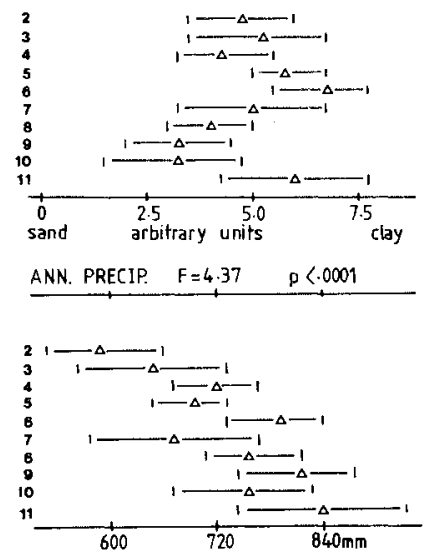

SLOPE

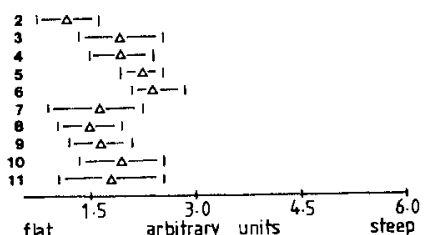

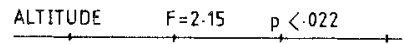

DRAINAGE $\quad F=1.55 \quad P<125$

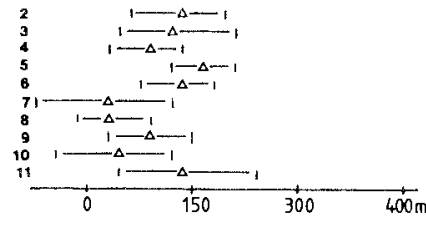

PRECIP. WETTEST MO. F $=5.39$ P $<.0001$
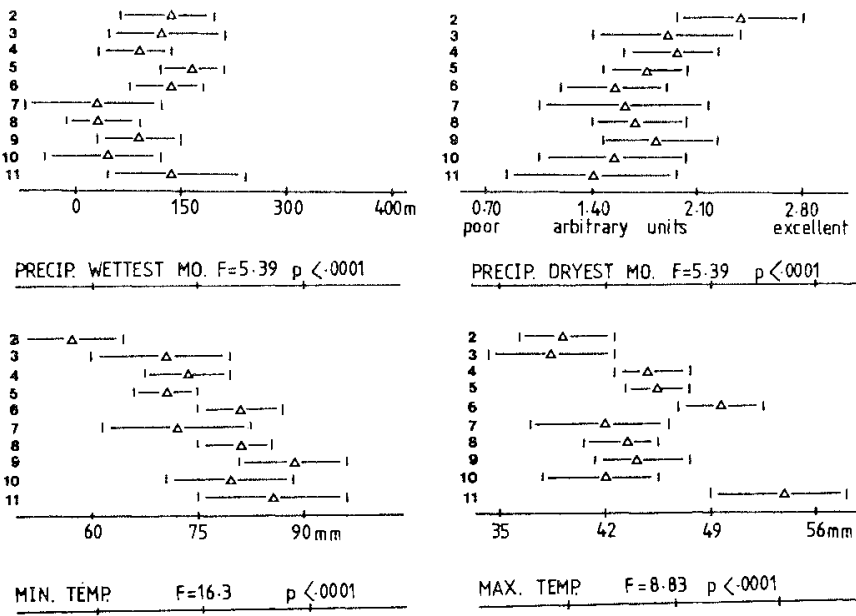

PRECIP. DRYEST MO. $F=5.39 \quad p<0001$

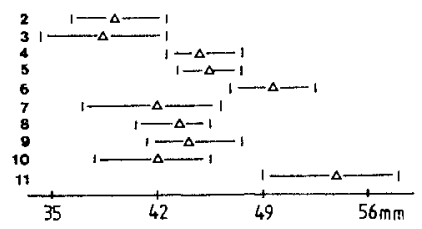

MAX. TEMP. $F=8.83 \quad p<-0001$
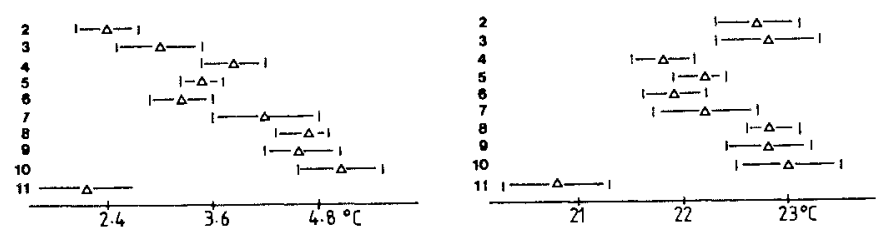
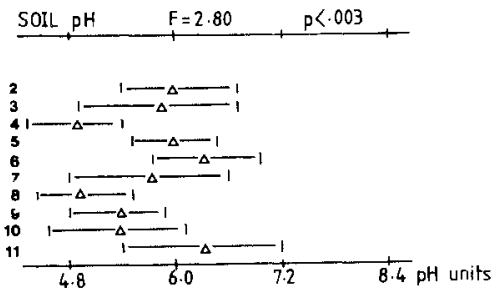

FlG. 2 - Means and 95\% confidence limits for communities on selected environmental variables (community (1) is excluded because of the low number of quadrats).

rocky ridges, rocky knolls or talus slopes. The understorey is variably shrubby or grassy. The community occupies a highly distinct microenvironment, which differentiates it from communities (4) and (7), and a macroclimatic zone distinct from that of most other communities.

(6) Eucalyptus globulus/E. obliqua-Callitris rhomboidea-Coprosma quadrifida shrubby woodland - This community occupies wetter sites than community (5), often on rocky talus slopes within steep gullies, but these sites are also usually on dolerite.
The community is marginal to wet eucalypt forest. Its macroclimate is significantly different from that of most other communities.

(7) Eucalyptus viminalis-Callitris rhomboideaBursaria spinosa woodland - This community occurs on deep, well-drained soils on disturbed sites, such as river banks and dunes along the central east coast. It is heavily invaded by exotic taxa.

(8) Eucalyptus globulus-Callitris rhomboideaAllocasuarina monilifera woodland - This community of the Bass Strait islands typically occurs 
on leachedsoils on granitic colluvium. The understorey is characterised by typical heath species, such as Allocasuarina monilifera and Leptospermum scoparium. Communities (9) and (10), also from Bass Strait, typically occur in places more subject to coastal influences than community (8), and community (9) also occurs on shallower soils. The Tasmanian mainland communities are climatically and edaphically distinct in their environmental range.

(9) Allocasuarina verticillata-Callitris rhomboidea Leptospermum laevigatum low closed forest - This Bass Strait island community occurs close to the coast on a variety of soils, most of which are shallow and acid. Like the previous community, it is climatically distinct in its range from the communities of the Tasmanian mainland.

(10) Callitris rhomboidea-Dodonaea viscosa closed scrub - This near-coastal Bass Strait island community has a climate that distinguishes it from most other communities, and tends to occur in slightly drier coastal situations than community (8).

(11) (Eucalyptus globulus)-Callitris rhomboideaBedfordia salicina (woodland) closed forest - This community occupies dolerite talus in extremely moist conditions, where Callitris is found mixed with species that extend to the rainforests of western Tasmania and is associated with a rich variety of hygrophilous ferns. It is climatically distinct from all others except community (1), which occupies a distinctly different topograhic situation.

The one-way analysis of variance indicated that the mean temperatures of the coldest and warmest months were the best discriminators between communities, followed by the precipitation of the wettest and driest months. There was less segregation of the communities in response to the topographic and soilrelated variables.

Although in most quadrats in most communities the Callitris species are subordinate to eucalypts, substantial porportions of the quadrats in groups (3), (8), (9), (10) and (11) have one of the two species as the sole dominant or a codominant (table 2). Thus, C. oblonga is most likely to be dominant in the tallest stratum in rocky riparian situations, whereas $C$. rhomboidea is most frequently dominant on the Bass Strait islands and the moistest part of its range on the Tasmanian mainland. Nevertheless, it is only in communities (1), (2) and (7) that there is no quadrat with Callitris as a dominant. These groups contain the most heavily human-disturbed sites in the survey.

The communities containing Callitris cover a substantial proportion of the environmental conditions found in eastern Tasmania. For example, soil $\mathrm{pH}$ varies from 3.0 to 8.5 , altitude from sea level to $575 \mathrm{~m}$, parent material frorn fertiie alluvium to deeply leached sand, frost climate from severe to frost free, precipitation from $500 \mathrm{~mm}$ per annum to $1400 \mathrm{~mm}$. Fourteen per cent of the Tasmanian native higher plant species were recorded from the 126 quadrats in the survey.

\section{GENERAL DISCUSSION}

The quadrat environmental data collected for this study indicate that the types of biophysical environments occupied by both species are far more extensive than their present ranges. Callitris oblonga is now largely restricted to the riparian zone of a few major rivers, yet can and does occur on shallow, well-drained soils well above the flood zone, and on at least one coastal sand dune system. It is totally absent from rivers identical in attributes to those from which it has been recorded. Similarly, with catholic tastes in soil and climate, $C$. rhomboidea has a surprisingly limited local occurrence and macrodistribution. For example, communities (4), (5) and (6) are virtually identical in their species composition, excluding $C$. rhomboidea, to wet and dry eucalypt forest communities known to occur widely in the Hobart region (Hogg \& Kirkpatrick 1974, Brown \& Bayly-Stark 1979b, Kirkpatrick et al. 1988). This pattern of distribution is consistent with the hypothesis that Callitris has a range reduced from its edaphic/ climatic potential by uncongenial disturbance regimes and a limited dispersal ability (cf. Clayton-Greene 1981, Bowman et al. 1988). Further evidence in relation to this question will be presented and discussed in our later papers.

Kirkpatrick (1989) postulated the existence of a dry rainforest formation covering much of eastern Tasmania before the invasion of people and suggests that the following east coast tree species are likely to be capable of gap phase regeneration without exogenous disturbance: Callitris rhomboidea, $C$. oblonga, Allocasuarina verticillata, A. littoralis, Asterotrichion discolor, Beyeria viscosa, Coprosma quadrifida, Dodonaea viscosa, Exocarpos cupressiformis, Pittosporum bicolor, Pomaderris apetala, Bedfordia salicina, Notelaea ligustrina and Olearia argophylla. It is notable that these species, and others identified by Jarman et al. (1984) as components of Tasmanian rainforest, are all found within the range of Callitris today (table 1 and appendix).

The putatively relict nature of Callitris in Tasmania makes it important to ensure that stands in a wide range of environments are protected from clearance or inappropriate disturbance regimes. Groups (1), (5), (6), (9), (10) and (11) are known from national parks or equivalent reserves. Group (2) is found within a private nature reserve established by the Tasmanian Conservation Trust Inc. Group (3) is found in the Gorge 
and the Trevallyn State Recreation Area. Group (4) is found near Cape Hauy in a forest reserve. Group (8) is found in the area under threat of alienation, but proposed for a nature reserve, at Wingaroo on Flinders Island. Group (7) is found in crown land at the coast at Orford. While some substantial populations of $C$. rhomboidea are found within reserves with first-class security and appropriately informed management, $C$. oblonga is a rare and threatened species with only one small private nature reserve being managed to the end of its preservation, and with most of its remaining populations, all small, being on private land. This taxon and the communities in which it occurs require active management if they are to survive another century. High concentrations of invasive, inflammable exotics make the future of most stands dependent on weed control,

The reservation and management programme that needs to be developed for Callitris communities in Tasmania will benefit two species of considerable horticultural worth that provide an interesting visual contrast in the eucalypt-dominated landscape of eastern Tasmania.

\section{ACKNOWLEDGEMENTS}

We thank Dennis Morris and Alex Buchanan for help with the identification of some plant specimens.

\section{REFERENCES}

BowMan, D.M.J.S., WILSON, B.A. \& DAVIS, G.W., 1988: Response of Callitris intratropica R.T. Baker \& H.G. Smith to fire protection, Murganella, Northern Australia. Aust. J. Ecol. 13: 147-159.

Brown, M.J., 1989: THE DISTRIBUTION AND CONSERVATION OF RING BILLY PINE. Tasmanian Forestry Commission, Hobart.

Brown, M.J. \& BAYLY-STARK, H.J., 1979a: Vegetation of Maria Island. Tasm. Nat. Pks Wildl. Serv., Wildl. Div.Tech. Rep. 79/1.

Brown, M.J. \& Bayly-StaRk, H.J., 1979b: The plant communities of the East Risdon Nature Reserve. Tasm. Nat. 58: 1-11.

Buchanan, A.M., McGeary-Brown, A. \& Orchard, A.E., 1989: A census of the vascular plants of Tasmania. Tasm. Herb. Occ. Publ. 2.

BUSBY, J.R., 1986: BIOCLIMATE PREDICTION SYSTEM (BIOCLIM) USERS MANUAL VERSION 2. Bureau of Flora and Fauna, Canberra.

Clayton-Greene, K.A., 1981: The autecology of Callitris collumellaris F. Muell. and associated Eucalyptus species in south-eastern Australia. Unpubl. PhD thesis, University of Melbourne.
CORBETt, J.R., 1969: THE LIVING SOIL. Geogr. Teach. Assoc. NSW, Como.

Cullen, P.J. \& Kirkpatrick, J.B., 1988: The ecology, distribution and conservation of Athrotaxis. Report to Australian Heritage Commission. Department of Geography and Environmental Studies, University of Tasmania.

DunCAN, F.D. \& Brown, M.J., 1985: Dry sclerophyll vegetation in Tasmania. Tasm. Natl. Pks Wildl. Serv., Wildl. Div. Tech. Rep. 85/1

DunCan, F. \& DunCan, D., 1984: A dry sclerophyll woodland mosaic: vegetation of Cherry Tree Hill, near Cranbrook, Tasmania. Rec. Q. Vict. Mus. 85.

Harris, S., 1989: The ecological biogeography of Callitris Vent. in Tasmania. Unpubl. MSc thesis, University of Tasmania.

HARRIS, S. \& Brown, M.J., 1980: The vegetation of Hellfire Bluff-Cape Bernier, Tasmania, Tasm. Nat. 62: 114.

HaRRIS, S. \& KirKPatrick, J.B., 1982: The vegetation of Schouten Island, Tasmania. Pap. Proc. R. Soc. Tasm. 116: 117-141.

HLL, M.O., 1979: TWINSPAN - A FORTRAN PROGRAM FOR ARRANGING MULTIVARIATE DATA IN A TWO-WAY TABLE BY CLASSIFICATION OF INDIVIUALS AND ATTRIBUTES. Cornell University, Ithaca

Hogg, A. \& KirkPATRICK, J.B., 1974: Phytosociology and synecology of some southern Tasmanian eucalypt forests and woodlands. J. Biogeog. 1: 227-245.

Jarman, S.J., Brown, M.J. \& Kantvilas, G., 1984: RAINFOREST IN TASMANIA. National Parks and Wildlife Service, Hobart.

KIRKPATRICK, J.B., 1977: THE DISAPPEARING HEATH. Tasmanian Conservation Trust, Hobart.

KIRKPATRICK, J.B,, 1989: The ecology and management of minor species.THE HUON FACTOR. University of Tasmania, Hobart: 21-24.

KiRKPatrick, J.B. \& Dickinson, K.J.M., 1984: The impact of fire on tasmanian alpine vegetation and soils. Aust. J. Bot. 32: 613-629.

Kirkpatrick, J.B., Peacock, R.J., Cullen, P.J. \& Neyland, M.G., 1988: THE WET EUCALYPT FORESTS OF TASMANIA. Tasmanian Conservation Trust, Hobart.

MiNCHIN, P.R., 1986: How to use ECOPAK: an ecological data base system. CSIRO Div. Land Use Res. Tech. Mem. 86/6.

SPECHT, R.L., 1981: Conservation of vegetation types. In Groves, R.H. (Ed.): AUSTRALIAN VEGETATION. Cambridge University Press, Cambridge.

\section{(accepted 10 August 1990)}

S. Harris

Department of Parks, Wildlife and Heritage, GPO Box 44A, Hobart, Tasmania, Australia 7001

J.B. Kirkpatrick

Department of Geography and Environmental Studies, University of Tasmania, GPO Box 252C, Hobart, Tasmania, Australia 7001 


\section{APPENDIX}

\section{Vascular Plant Species in Association with Callitris}

Recorded from quadrat samples throughout the Tasmanian range of $C$. rhomboidea and $C$. oblonga. Nomenclature follows B uchanan et al. (1989) except for Olearia archeri Lander and Cupressus macrocarpa Hartw.

\section{DICOTYLEDONS}

AIZOACEAE (FICOIDEAE)

Carpobrotus rossii

Tetragonia implexicoma

APIACEAE (UMBELLIFERAE)

Daucus glochidiatus

Hydrocotyle sp.

Hydrocotyle hirta

Hydrocotyle sibthorpioides

Xanthosia pilosa

Xanthosia tridentata

APOCYNACEAE

Vinca major

ASTERACEAE (COMPOSITAE)

Arcto theca calendula

Bedfordia linearis

Bedfordia salicina

Brachyscome aculeata

Brachyscome decipiens

Brachyscome parvula

Brachyscome rigidula

Cassinia aculeata

Cirsium vulgare

Gnaphalium collinum

Helichrysum antennarium

Helichrysum apiculatum

Helichrysum costatifructum

Helichrysum dendroideum

Helichrysum lycopodioides

Helichrysum obcordatum

Helichrysum scorpioides

Helichrysum scutellifolium

Hypochoeris glabra

Hypochoeris radicata

Lagenifera stipitata

Leontodon taraxacoides

Leptorhynchos squamatus

Odixia angusta

Olearia archeri Lander

Olearia argophylla

Olearia ericoides

Olearia lepidophylla

Olearia lirata

Olearia myrsinoides

Olearia persoonioides

Olearia phlogopappa

Olearia stellulata

Olearia viscosa

Senecio sp.

Senecio gunnii

Senecio hispidulus

Senecio lautus
Senecio linearifolius

Senecio minimus

Senecio quadridentatus

Sonchus sp.

Sonchus asper

Sonchus oleraceus

BRASSICACEAE (CRUCIFERAE)

Cardamine sp.

Rorippa sp.

CAMPANULACEAE

Wahlenbergia sp.

Wahlenbergia gracilenta

Wahlenbergia gymnoclada

CARYOPHYLLACEAE

Cerastium fontanum Baumg.

Polycarpon tetraphyllum

Silene sp.

CASUARINACEAE

Allocasuarina littoralis

Allocasuarina monilifera

Allocasuarina verticillata

CHENOPODIACEAE

Rhagodia candolleana

CLUSIACEAE (GUTTIFERAE)

Hypericum gramineum

CONVOLVULACEAE

Dichondra repens

CRASSULACEAE

Crassula sieberana

CUNONIACEAE

Bauera rubioides

DILLENIACAEAE

Hibbertia aspera

Hibbertia empetrifolia

Hibbertia hirsuta

Hibbertia prostrata

Hibbertia riparia

Hibbertia serpyllifolia

DROSERACEAE

Drosera peltata

ELAEOCARPACEAE

Elaeocarpus reticulatus

EPACRIDACEAE

Acrotriche serrulata

Astroloma humifusum

Astroloma pinifolium

Cyathodes divaricata

Cyathodes glauca

Cyathodes juniperina

Epacris gunnii

Epacris impressa

Epacris lamuginosa 
Epacris marginata Epacris paludosa Epacris tasmanica Leucopogon collinus Leucopogon ericoides Leucopogon parviflorus Lissanthe strigosa Monotoca elliptica Monotoca glauca ESCALLONIACEAE Anopterus glandulosus EUPHORBIACEAE Amperea xiphoclada Beyeria viscosa Micrantheum hexandrum Phyllanthus ausiralis Phyllanthus gunnii Poranthera microphylla Ricinocarpus pinifolius

FABACEAE (LEGUMINOSAE) Acacia axillaris Acacia dealbata Acacia genistifolia - Acacia mearnsii Acacia melanoxylon Acacia mucronata Acacia myrtifolia Acacia sophorae Acacia stricta Acacia suaveolens Acacia terminalis Acacia verniciflua Acacia verticillata Aotus ericoides Bossiaea cinerea Bossiaea prostrata Daviesia ulicifolia Dillwynia cinerascens Dillwynia glaberrima Dillwynia sericea Glycine clandestina Gompholobium huegelii Goodia lotifolia

Hovea lanceolata

Hovea linearis

Indigofera australis

Platylobium formosum

Platylobium triangulare

Pultenaea daphnoides var obcordata

Pultenaea gunnii

Pultenaea juniperina

Pultenaea pedunculata

Pultenaea stricta

Sphaerolobium vimineum

Trifolium dubium

Trifolium repens

Ulex europaeus

Vicia sp.

GENTIANACEAE

Centaurium erythraea

\section{GERANIACEAE}

Geranium potentilloides

Geranium solanderi

Pelargonium inodorum

GOODENIACEAE

Dampiera stricta

Goodenia elongata

Goodenia lanata

Goodenia ovata

HALORAGACEAE

Gonocarpus micranthus

Gonocarpus tetragynus

Gonocarpus teucrioides

LAMIACEAE (LABIATAE)

Ajuga australis

Mentha diemenica

Prostanthera lasianthos

Prunella vulgaris

LAURACEAE

Cassytha glabella

Cassytha melantha

Cassytha pubescens

MALVACEAE

Asterotrichion discolor

MONIMIACEAE

Atherosperma moschatum

MYOPORACEAE

Myoporum insulare

MYRTACEAE

Baeckea ramosissima

Callistemon paludosus

Calytrix tetragona

Eucalyptus amygdalina

Eucalyptus delegatensis

Eucalyptus globulus

Eucalyptus nitida

Eucalyptus obliqua

Eucalyptus ovata

Eucalyptus pulchella

Eucalyptus regnans

Eucalyptus tenuiramis

Eucalyptus viminalis

Kunzea ambigua

Leptospermum glaucescens

Leptospermum grandiflorum

Leptospermum laevigatum

Leptospermum lanigerum

Leptospermum scoparium

Melalenca ericifolia

Melalenca gibbosa

Melaleuca pustulata

Melaleuca squarrosa

OLEACEAE

Notelaea ligustrina

ONAGRACEAE

Epilobium sp.

OXALIDACEAE

Oxalis corniculata

PITTOSPORACEAE

Billardiera longiflora 
Billardiera procumbens

Bill ardiera scandens

Bursaria spinosa

Pittosporum bicolor

PLANTAGINACEAE

Plantago lanceolata

Plantago varia

POLYGALACEAE

Comesperma volubile

POLYGONACEAE

Muehlenbeckia adpressa

Rumex acetosella

Rumex brownii

PRIMULACEAE

Anagallis arvensis

PROTEACEAE

Banksia marginata

Grevillea australis var linearifolia

Hakea lissosperma

Hakea sericea

Hakea teretifolia

Lomatia tinctoria

Persoonia juniperina var juniperina

RANUNCULACEAE

Clematis aristata

Clematis gentianoides

Ranunculus sp.

RHAMNACEAE

Pomaderris apetala

Pomaderris elliptica

Pomaderris pilifera

Spyridium microphyllum

Spyridium obovatum

Spyridium vexilliferum

Stenanthemum pimeleoides

ROSACEAE

Acaena echinata

Acaena novae-zelandiae

Crataegus monogyna

Rosa rubiginosa

Rubus fruiticosus

Rubus parvifolius

RUBIACEAE

Coprosma hirtella

Coprosma quadrifida

Galium australe

Galium ciliare

Galium gaudichaudii

RUTACEAE

Boronia anemonifolia

Boronia citriodora

Boronia pilosa

Correa lawrenciana

Correa reflexa

Eriostemon verrucosus

Phebalium bilobum

Phebalium squameum

Zieria arborescens

SANTALACEAE

Exocarpos cupressiformis

Exocarpos syrticola
Leptomeria drupacea

SAPINDACEAE

Dodonaea viscosa

SCROPHULARIACEAE

Veronica calycina

Veronica formosa

SOLANACEAE

Solanum laciniatum

Solanum nigrum

STACKHOUSIACEAE

Stackhousia monogyna

STERCULIACEAE

Lasiopetalum baueri

Lasiopetalum micranthum

STYLIDIACEAE

Stylidium graminifolium

THYMELAEACEAE

Pimelea drupacea

Pimelea flava

Pimelea humilis

Pimelea nivea

TREMANDRACEAE

Tetratheca labillardierei

Tetratheca pilosa

URTICACEAE

Australina pusilla

Urtica incisa

VIOLACEAE

Viola sp.

Viola hederacea

WINTERACEAE

Tasmannia lanceolata

ZYGOPHYLLACEAE

Zygophyllum billardieri

MONOCOTYLEDONS

CENTROLEPIDACEAE

Centrolepis strigosa.

CYPERACEAE

Baumea juncea

Carex breviculmis

Carexiynx

Carex longebrachiato

Eleocharis acuta

Gahnia graminifolia

Gahnia grandis

Gahnia microstachya

Gahnia radula

Gahnia trifida

Isolepis cernua

Isolepis nodosa

Isolepis subtilissima

Lepidosperma concavum

Lepidosperma elatius

Lepidosperma laterale

Lepidosperma lineare

Lepidosperma longitudinale

Schoenus apogon

Tetraria capillaris

HYPOXIDACEAE

Hypoxis glabella 


\section{IRIDACEAE}

Diplarrena moraea

Iris foetidissima

Patersonia fragilis

JUNCACEAE

Juncus pallidus

Juncus pauciflorus

Luzula sp.

Luzula novae-cambriae

LILIACEAE

Arthropodium minus

Bulbine bulbosa

Bulbine semibarbata

Dianella revoluta

Dianella tasmanica

ORCHIDACEAE

Caladenia sp.

Caladenia catenata

Dendrobium striolatum

Pterostylis longifolia

Thelymitra sp.

POACEAE (GRAMINEAE)

Agrostis capillaris

Agrostis parviflora

Agrostis stolonifera

Aira caryophyllea

Briza maxima

Bromus diandrus

Bromus sterilis

Cynosurus echinatus

Danthonia caespitosa

Danthonia dimidiata

Danthonia pilosa

Danthonia racemosa

Danthonia semiannularis

Danthonia setacea

Deyeuxia accedens

Deyeuxia monticola

Deyeuxia quadriseta

Dichelachne rara

Ehrharta distichophylla

Ehrharta stipoides

Holcus lanatus

Phalaris aquatica

Phragmites australis

Poa sp.

Poa labillardieri

Poa poiformis

Poa rodwayi

Poa sieberiana

Stipa sp.

Stipa aphylla

Stipa mollis

Stipa pubinodis

Stipa rudis

Themeda triandra

\section{RESTIONACEAE}

Hypolaena fastigiata

Leptocarpus brownii

Leprocarpus tenax

XANTHORRHOEACEAE

Lomandra longifolia

Lomandra nana

Xanthorrhoea australis

GYMNOSPERMS

CUPRESSACEAE

Callitris oblonga

Callitris rhomboidea

Cupressus macrocarpa Hartw.

PHYLLOCLADACEAE

Phyllocladus aspleniifolius

PTERIDOPHYTES

ADIANTACEAE

Adiantum aethiopicum

ASPIDIACEAE

Polystichum proliferum

ASPLENIACEAE

Asplenium flabellifolium

BLECHNACEAE

Blechnum nudum

Blechnum wattsii

DAVALLIACEAE

Rumohra adiantiformis

DENNSTAEDTIACEAE

Histiopteris incisa

Pteridium esculentum

DICKSONIACEAE

Dicksonia antarctica

GRAMMITIDACEAE

Ctenopteris heterophylla

Grammitis billardieri

HYMENOPHYLLACEAE

Hymenophyllum cupressiforme

Hymenophyllum flabellatum

Hymenophyllum peltatum

Hymenophyllum rarum

LINDSAEACEAE

Lindsaea linearis

LYCOPODIACEAE

Lycopodium varium

POLYPODIACEAE

Microsorum diversifolium

SELAGINELLACEAE

Selaginella uliginosa

SINOPTERIDACEAE

Cheilanthes austrotenuifolia

Pellaea falcata 